\title{
Simulation is a valuable tool for team training
}

\author{
Andrea J. Carpenter, MD, $\mathrm{PhD}$
}

\author{
From the Department of Thoracic Surgery, University of Texas Health San Antonio, San Antonio, Tex. \\ Disclosures: Author has nothing to disclose with regard to commercial support. \\ Received for publication Jan 21, 2018; accepted for publication Jan 26, 2018; available ahead of print March 13, \\ 2018. \\ Address for reprints: Andrea J. Carpenter, MD, PhD, Department of Cardiothoracic Surgery, University of Texas \\ Health San Antonio, 7703 Floyd Curl, MC 7841, San Antonio, TX 78229 (E-mail: carpentera2@uthscsa.edu). \\ J Thorac Cardiovasc Surg 2018;155:2525 \\ $0022-5223 / \$ 36.00$ \\ Copyright (C) 2018 by The American Association for Thoracic Surgery \\ https://doi.org/10.1016/j.jtcvs.2018.01.046
}

The value of simulation as a training tool has been best proved in the airline industry, where frequent training in complex, high-fidelity simulators has proved to improve air travel safety. In 2007, leaders from several cardiothoracic organizations, the American College of Surgery, members of airline safety groups, and simulation developers gathered in Boston to envision how simulation could benefit our specialty. ${ }^{1}$ Since then, simulation has slowly been adopted for resident training, and a decade's worth of Thoracic Surgery Directors Association boot camps have demonstrated the value of simulation with respect to skills development. ${ }^{2}$ Only recently have complex simulations begun to validate the benefit of team training. ${ }^{3}$

In this issue of the Journal, Joyce and colleagues ${ }^{4}$ present a complex simulation that allows multiple participants to perform in the various roles of operating room scenarios. In this article, they describe methods of observing simulations and rating individual performances with surgical residents and nurses performing various roles. The real value of this article is that it provides one of very few demonstrations of the effectiveness of simulating team activities. Bringing together the actual participants of a team to practice operative or critical care events can be an incredibly powerful tool for improving patient safety. We can easily see that practicing rare events as a functional team can be lifesaving when such an event occurs. More subtly, team practice improves team cooperation and empowers every team member to speak and act in real patient care situations.

Surgical simulators are a long way from offering the fidelity that aircraft simulators provide. As such, the highstakes use of simulation for practitioner evaluation or certification is currently science fiction. Today, however,

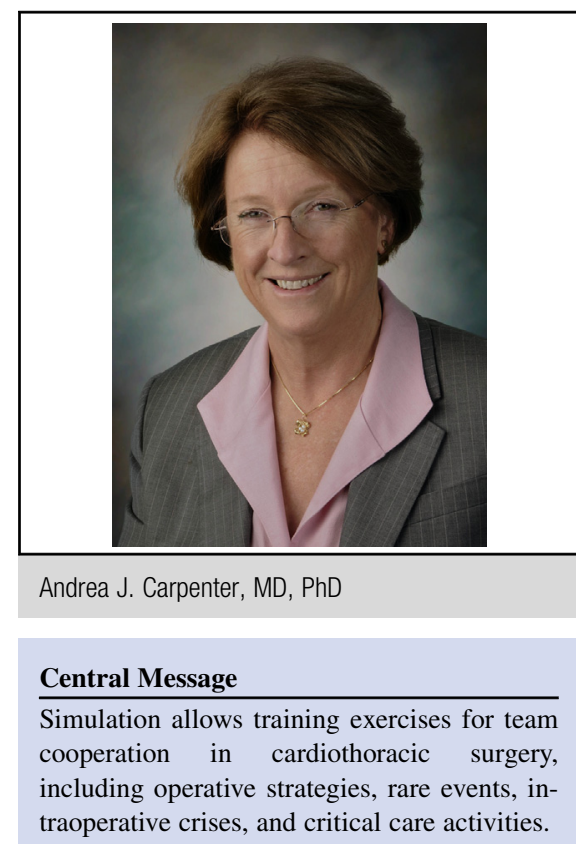

See Article page 2518 .

relatively simple simulations can already be used to practice rare events, foster team performance, and improve patient safety. Effective simulation will require a real commitment in time and money but potentially carries real benefits. These activities should be encouraged in all our practice environments.

\section{References}

1. Carpenter AJ, Yang SC, Uhlig PN, Colson YL. Envisioning simulation in the future of thoracic surgical education. J Thorac Cardiovasc Surg. 2008; 135:477-84.

2. Fann JI, Sullivan ME, Skeff KM, Stratos GA, Walker JD, Grossi EA, et al. Teaching behaviors in the cardiac surgery simulation environment. J Thorac Cardiovasc Surg. 2013;145:45-53.

3. Fung L, Boet S, Bould MD, Qosa H, Perrier L, Tricco A, et al. Impact of crisis resource management simulation-based training for interprofessional and interdisciplinary teams: a systematic review. J Interprof Care. 2015;29:433-44.

4. Joyce DL, Lahr BD, Maltais S, Said SM, Stulak JM, Nuttall GA, et al. Integration of simulation components enhances team training in cardiac surgery. J Thorac Cardiovasc Surg. 2018;155:2518-24.e5. 